\title{
リンパ浮腫に対するリハビリテーション・アプローチ
}

\author{
細川賀乃子*1 近藤 和 泉*1 岩田 学 $* 2$
}

\section{Lymphedema Rehabilitation}

\author{
Kanoko Hosokawa, ${ }^{* 1}$ Izumi Kondou, ${ }^{* 1}$ Manabu Iwata *2
}

\begin{abstract}
Lymphedema is defined as a swelling of the arms or legs induced by an obstruction in lymph fluid circulation or by an abnormality in lymph fluid production. In most patients, lymphedema can be diagnosed from the clinical history and physical examination. The lymphangiogram and lymphangioscintigraphy are also used as additional diagnostic tools. Lymphedema developed from an obstruction of the lymphatic system is called secondary lymphedema. Lymphedema is classified into two categories: primary and secondary, and primary lymphedema is rare and is caused by a defect at birth or a congenital lymph system abnormality. The most frequent complication with lymphedema is cellulites. The protein-rich lymph fluid can be a source of bacteria proliferation leading to cellulites, which is an infection in the subcutaneous layers. But if therapy is started from the onset, the risk of infection in edema patients can be lessened. The primary management of lymphedema consist of conservative treatment called complex decongestive physical therapy: CDP or decongestive lymphatic therapy: DLT. The treatment includes skin care, manual lymph drainage, compression therapy, and exercise with bandage or compression garment. If the conservative management does not produce a sufficient effect or the edema worsens, surgical interventions such as microsurgical lymphaticovenular anastomosis and other techniques may be indicated. In Japan, the health insurance system does not offer enough support for patients with lymphedema. The treatment of lymphedema from the early stage is usually effective, and it is therefore necessary for clinicians to have a working knowledge of lymphedema management.
\end{abstract}

Key words : リンパ浮腫 (lymphedema), 診断 (diagnosis), 複合的疎泄理学療法 (decongestive lymphatic therapy), 用手的リンパドレナージ (manual lymph drainage), 圧迫 療法 (compression therapy)

\section{はじめに}

\section{主にがん治療後の後遺症として出現することの} 多いリンパ浮腫は, 単なる腫れのみならず, 症状 が長期にわたると日常生活上の制限が出現し，ま た異常な腫脹から周りの目を気にしながらの生活 は患者に大きな負担を強いる。
ここでは，主にリンパ・リンパ系とはどのよう なものか，また，その障害で起きるリンパ浮腫の 診断, 合併症と, 治療, また生活上の留意点や現 在の問題点などについて述べ, リンパ浮腫のリハ ビリテーション（以下，リハ）を行う上で必要な 知識について総括したい.

2005 年 4 月 14 日受稿

*1 弘前大学医学部附属病院リハビリテーション部/テ 036-8563 青森県弘前市本町 53

Rehabilitation Center, Hirosaki University Hospital

*2 弘前大学医学部保健学科理学療法学専攻/ T 036-8564 青森県弘前市本町 66-1

Department of Physical Therapy, Hirosaki University, School of Health Sciences

E-mail : noukenrh@mail.cc.hirosaki-u.ac.jp 


\section{リンパ浮腫を理解するために}

\section{1. リンパ浮腫治療の背景}

リンパ浮腫という疾患は，これまで患者の実数 や発症率などに対する調査がほとんど行われてこ なかった. 1988 年の旧厚生省の特定疾患系統的 脈管障害調査研究班によるリンパ浮腫患者に関す る全国調査では, リンパ浮腫の発症率は $25 \%$ 前 後と言われているが1), 全国規模で患者数の集計 を行っている報告は無い. しかし, 乳がんや子宮 がんの患者発生率を考えると，年間 5 千人以上 ががん治療後にリンパ浮腫を発症していると推定 される.

\section{2. リンパ・リンパ管とその構造}

体液を運搬する循環系には, 動脈, 静脈とリン パ管があり，リンパ管により運ばれる体液成分を リンパと呼ぶ.リンパ管は皮膚直下で毛細リンパ 管から始まり，全身の末梢組織に網目状に広がり

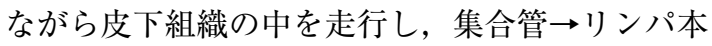
管 ヤリンパ節を経て深部リンパ管となり徐々に合 流しながら最終的に静脈へと流入する ${ }^{2)}$. 中枢側 のリンパ管には弁構造があるが，毛細リンパ管に はない. 表層のリンパ管が深部リンパ管に連絡す る経路は限られており, 頸部・腋窩部・鼠径部が その部位である ${ }^{3)}$.

末梢では，毛細血管から栄養分を多く含む血漿 成分が漏れ出し細胞を栄養し，老廃物を交換する ため細胞の隙間を組織間液が満たしている。臓 から拍出される血液量は約 $2,400 \mathrm{l} /$ 日で，そのう ち毛細血管の動脈側から組織へと漏れ出る血漿成 分の量は約 $20 l /$ 日とされているが，その中には, 水分, 電解質などとともに少量の蛋白質が含まれ ている，毛細血管から組織を栄養するため漏れ出 したうちの約 $90 \%$ は静脈から，約 10\%は組織間 液からリンパ管に吸収されて運搬される ${ }^{4)}$. 漏れ だした血漿成分中の蛋白質漏出量は 75〜 $195 \mathrm{~g} /$ 日で，ほとんどは毛細血管へ再吸収されずリンパ 管内へ移行する ${ }^{4)}$.

両下肢からのリンパ管は腹腔内で合流し，さら
に腹腔臓器からのリンパ，左上半身からのリンパ と合流して乳び槽となり左静脈角から静脈へ流入 する. 同じく右上半身からのリンパは右静脈角よ り静脈へと流入している（図1）.

\section{3. リンパ管へのリンパ液の取り込みと輸送}

組織間液の取り込みは毛細リンパ管の末端部で 行われている，毛細リンパ管は，リンパ管繋留フ イラメント (lymphatic anchoring filament) によ り周囲の組織と付着しており, 組織間液が貯留し てくるとフィラメントにより毛細リンパ管が周囲 方向へ引っ張られて，管壁にあるすきまが広がり 組織間液が毛細リンパ管内へ吸い达まれる ${ }^{3)}$. 毛 細リンパ管内が満たされると, 周囲組織の平滑筋 や内皮細胞自体の収縮により毛細リンパ管が圧迫 されリンパ液は中枢へと送られる。リンパ管の自 動収縮によるリンパ輸送も認められるが，多くは 受動収縮によるものであり, 特に, 筋活動時は四 肢からのリンパ流は 4〜20 倍に増加する ${ }^{4}$.

\section{4. リンパ管の分水嶺}

末梢の毛細リンパ管はお互いが網目状に結合し 合っているが，部分的にその結合がそしい境界部 があり，それをリンパ管の分水嶺と呼んでいる (図 1 $)^{3)}$.

リンパ管の障害部位が分水嶺に対してどの場所 に属するかで, 浮腫の出る可能性のある部位がわ かる，例えば，右鼠径部のリンパ節郭清術後であ れば右下肢〜右下腹部とその背部に，左腋窩リン パ節の郭清術後には左上肢〜左前胸部とその背部 に浮腫が出る可能性がある。ただし，リンパ管の 障害が起きても, 毛細リンパ管は網目状に結合し ながら広がり弁構造を持たずバイパスとしての機 能を持ち，また，人体には代償機能があるため， リンパ節郭清術後に必ず浮腫が出現するわけでは ない.

\section{リンパ浮腫とは何か}

\section{1. なぜ浮腫が起きるか}

リンパ浮腫とは, リンパ管や節の発育不全また 


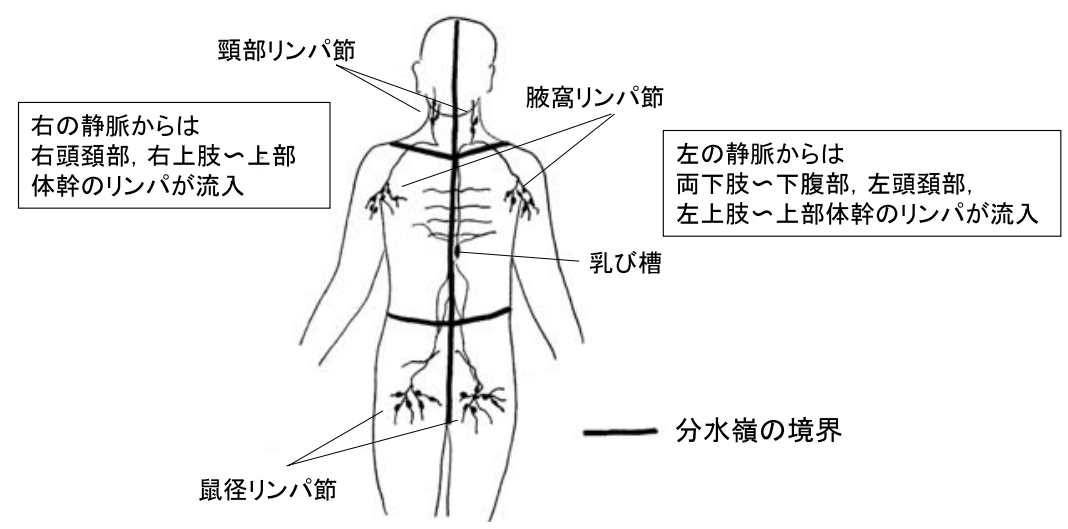

図 1 リンパ管の分水嶺

線の部分で毛細リンパ管同士の結合がそしく，障害されているリンパ節によって障害 部位が予測される.

表 1 リンパ浮腫の分類方法

\begin{tabular}{|c|c|c|}
\hline 一次性リンパ浮腫 & $\begin{array}{l}\text { 先天性リンパ浮腫 } \\
\text { 早発性リンパ浮腫 } \\
\text { 晚発性リンパ浮腫 }\end{array}$ & $\begin{array}{l}\text { 生下時または生後 } 2 \text { 年以内に発症 } \\
2 \text { 歳から } 35 \text { 歳までに発症 } \\
35 \text { 歳以降に発症 }\end{array}$ \\
\hline 二次性リンパ浮腫 & $\begin{array}{l}\text { 子宮がんや卵巣がん, } \\
\text { 部からの原因によるリ } \\
\text { どにより発症する. } \\
\text { もともとのリンパ管の }\end{array}$ & $\begin{array}{l}\text { 乳がんの手術後などのように，外 } \\
\text { ンパ管の解剖学的な閉鎖・欠損な } \\
\text { 構造には問題がない. }\end{array}$ \\
\hline
\end{tabular}

は圧迫, 狭窄, 閉塞などにより, リンパ流の阻害 と減少のために生じた浮腫である.リンパの流れ が不良となると蛋白質を多く含むリンパ液が皮下 に貯留し，膠質浸透圧（膠質圧）により貯留した 蛋白質が水を引きつけることで浮腫が出現する.

\section{2. リンパ浮腫の分類}

リンパ浮腫の臨床分類としては, 先天性のもの を含めた，原因が明らかではない一次性と，明ら かな原因のある二次性とに分類され5,6)（表 1), 後者がリンパ浮腫患者の約 80〜 90\%を占めてい る7). 婦人科で加療される子宮がん・卵巣がんや, 乳がんの術後に発症することが多いため, リンパ 浮腫患者の大多数が女性である. 最近の国際分類 によると, 乳がんの術後 10 年間で $24 \sim 28 \%{ }^{8)}$, 子宮がんの術後 10 年間で 40〜 $50 \%$ にリンパ浮腫 が発症すると報告されている ${ }^{9)}$.

\section{リンパ浮腫の診断と評価}

\section{1. 診 断}

最も簡単な浮腫の評価方法は周径測定である ${ }^{10)}$. 測定部位は図 2 のような部位が挙げられるが, 同一部位で経過を追って測定することで経時的変 化をとらえることができる. 通常, 浮腫がなくて も左右の周径差はあるが, 上肢では一般的には測 定したいずれかの部位で $2 \mathrm{~cm}$ を越えて周径差が ある場合 ${ }^{11)}$, 下肢では明確な基準はないが 2 $3 \mathrm{~cm}$ 前後の周径差を認める場合にはリンパ浮腫 としている.

リンパ浮腫は緩徐進行性の痛みのない浮腫であ るが，発症初期や急激に浮腫が進行した際には， 皮膚の緊満感やピリピリとした痛みを自覚するこ ともある.また経過が長くなると重量感と共にだ るさ, 患肢の挙上困難なども出現する場合があり, 周径以外の症状にも注意を要する。 

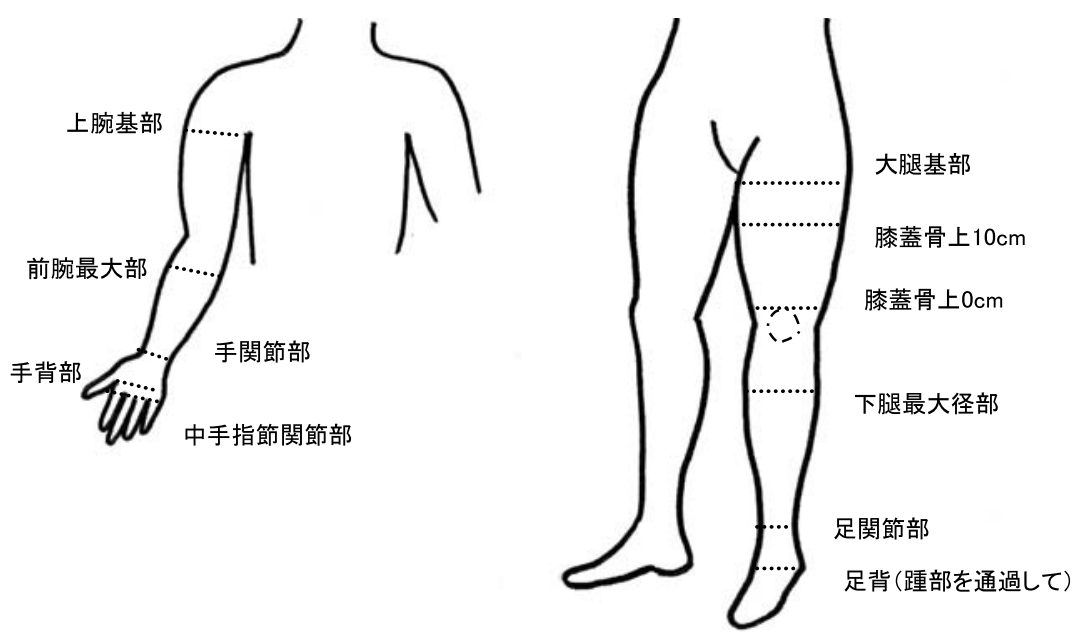

図 2 上肢, 下肢周径測定部位の例

表 2 下肢で多くみられる浮腫の鑑別診断（文献 10 より一部改変）

\begin{tabular}{|c|c|c|c|}
\hline & リンパ浮腫 & 静脈性浮腫 & 心性浮腫 \\
\hline 発症部位 & $\begin{array}{l}\text { 肢全体にあり } \\
\text { 時に両側性 }\end{array}$ & 通常は片側性 & $\begin{array}{l}\text { 全身性で未梢に高度な } \\
\text { 浮腫 }\end{array}$ \\
\hline 性状 & $\begin{array}{l}\text { 初期は圧痕ができる } \\
\text { が, 進行すると圧痕の } \\
\text { できない固いむくみ }\end{array}$ & 緊満感あり & $\begin{array}{l}\text { 压痕ができる柔らかな } \\
\text { むく }\end{array}$ \\
\hline 皮膚の変化 & $\begin{array}{l}\text { 基本的には白. 皮虐の } \\
\text { 肥厚, 進行すると象皮 } \\
\text { 様. 多毛. }\end{array}$ & $\begin{array}{l}\text { 色素沈着あり, 潰痬な } \\
\text { どが認められることも }\end{array}$ & 光沢, 軽度の色素沈着 \\
\hline 疼痛など & 通常は無〜軽度 & 重量感, 緊満感 & なし \\
\hline
\end{tabular}

アメリカがん協会 (American Cancer Society) の報告によると，乳がん術後 3 力月前後は手術 自体による侵襲のため, 術側上肢の浮腫が起こり やすい状態であるが，早期，特に乳がん術後 1 カ月以内に浮腫が認められる場合には, リンパ浮 腫発症のリスクがあるとして注意深い観察を要す るとしている12).

\section{2. 鑑別診断}

リンパ浮腫以外にも浮腫を生じる疾患は種々あ る、ただし, 上肢のみ, 特に片側のみの浮腫は少 ないためリンパ浮腫の診断が容易であるが，下肢 では浮腫が認められるその他の疾患も多い13).

鑑別疾患として四肢の各部位がびまん性に腫脹 する疾患が挙げられ, 特に静脈性浮腫（深部静脈 血栓症）には注意を払う必要がある. 静脈性浮腫,
心疾患による浮腫との鑑別点を（表 2）に示した ${ }^{10)}$.

\section{3. 検 查}

二次性リンパ浮腫は既往歴や問診. 経過により 比較的診断が容易だが，一次性では浮腫が出現し た際に発症の要因となるような既往歴がないこと が多く，リンパ流の障害の有無や程度などの評価 が診断上補助的に使われる場合がある。リンパ機 能の測定方法としては，リンパ管シンチグラフィ 一, リンパ管造影がある ${ }^{14)}$.

リンパ管シンチグラフィーは，放射線活性を持 つ蛋白質やコロイドを皮下へ注入し，リンパ管へ の取り达みを描出するものである。まだ手技とし て標準化されておらず，鑑別診断などに有用と思 われるが苦痛を伴うこともあり一般化されてはい ない. 
リンパ管造影は侵襲が強く, 施行後に浮腫の進 行や感染などを引き起こす危険性もあり, 診断の みの目的ではあまり施行されなくなってきてい る.

リンパ浮腫では皮膚や皮下にリンパ液が貯留し 線維化を来すが，非侵襲的な検査である CT や MRI，超音波検査でもその程度を観察できる．体 脂肪や筋肉量, 四肢体幹の細胞内・外液を体組成 計によって測定する生体インピーダンス測定法が あるが，これを乳がん術後に経時的に測定するこ とで周径差が出る前から発症を予測できたという 報告15）もあり，リンパ浮腫を早期発見する手が かりとなる可能性がある.

\section{4. 重症度分類}

リンパ浮腫は一般には硬く, くぼみのできない 浮腫といわれるが, 発症の初期には柔らかく指で 押すとくぼみができる，この頃は，患肢を挙上す ることで浮腫の減少が認められる時期でもある. しかし, 時間が経過してゆくことで, 皮下組織に 線維化が起こり, 浮腫がより硬くなり圧迫しても くぼみができないようになる，また挙上のみで浮 腫が軽減することが難しくなってくる.

国際リンパ学会 (International Society of Lymphology : ISL) ではリンパ浮腫の進行度を臨床的 に 3 段階に分類し, 圧迫時の圧窩と線維化の程 度により区別されている16). Foeldi らは, 自覚症 状はないものの，皮下への水分貯留が始まった時 期を 0 期，または潜伏期として新たな段階を加

\section{えた分類を行っている（表 3 ${ }^{17)}$.}

潜伏期は, 臨床的には浮腫はないがリンパ管造 影を行うと異常が確認される時期で, バイパス機 能によりリンパ液の吸収・運搬が行われることで 浮腫の発症を避けられている.リンパ液が増量す るような出来事, たとえば, 軽微な外傷や虫ささ れなどをきっかけに，処理できる以上に血管から の水分・蛋白の漏出が起きることで浮腫が顕在化 する. 特に, 二次性のリンパ浮腫患者では, 前述 のようにむくみを感じる以前から患肢の重だるさ や緊満感などを感じることもよくあり, 潜伏期か ら浮腫の発症を予防するため生活上の注意をし, 浮腫が出現した場合は早期から対応できるように することが大切である.

\section{5. リンパ浮腫の合併症}

\section{1）蜂窩織炎}

リンパ浮腫に合併して起こりやすい皮下の炎症 性疾患である。急性の細菌感染で, 浮腫のある部 位の発赤や発疹, 腫脹, 疼痛, 熱感などが急速に 進行し,さらに 38 度以上の熱発や悪寒戦慄など 全身症状を伴うことも多い。一般には，抗生剤の 投与, 安静, 患肢の挙上, クーリングなどを併用 し 2 3 日で軽快する ${ }^{18)}$ が，感染を繰り返すこと もある. 発症の予防が大切であり，スキンケアを 励行し, 傷をつくった場合は消毒など速やかな対 応が必要である。

また，抗がん剤での治療中にも発症することが あり，がん治療目的に化学療法施行中の二次性り

表 3 国際リンパ学会によるリンパ浮腫重症度分類

\begin{tabular}{c|l}
\hline Stage & \multicolumn{1}{|c}{ 基 準 } \\
\hline 0 & $\begin{array}{l}\text { まだ浮腫の発症はなく自覚症状は認めないが, 皮下にリンパ液の譻留が } \\
\text { ある (潜在的). }\end{array}$ \\
\hline I & $\begin{array}{l}\text { 浮腫が認められるが, 線維化はない, またはわずか. } \\
\text { 圧迫により圧痕つくり, 患肢の挙上で浮腫が軽減する. } \\
\text { 健側周径の< } 20 \% \text { の増加 }\end{array}$ \\
\hline II & $\begin{array}{l}\text { 患肢の挙上のみでは浮腫の改善は認められない. } \\
\text { 压ができるが, 線維化が進行してくると圧痕は認められない. } \\
\text { 健側周径の } 20 〜 40 \% \text { の増加 }\end{array}$ \\
\hline III & $\begin{array}{l}\text { 象皮病の状態となり, 圧迫で圧痕ができない. } \\
\text { 健側周径の>40\%の増加 }\end{array}$ \\
\hline
\end{tabular}

Stage 0 の段階をつけない場合もある. 
ンパ浮腫患者では浮腫の増強や発赤，痛みの出る 危険性があることを伝え, 発症した場合はすぐに 加療する。

\section{2）急性炎症性変化（急性皮膚炎）}

蜂窩織炎類似の発赤と腫脹, 熱感などが認めら れるが全身症状が無く，また蜂窩織炎のように血 液検査で炎症反応を認めない。蜂窩織炎と異なり 抗生物質では改善しないことが多く, 発赤や浮腫 の状態を見ながら通常のリンパ浮腫の治療を行 ${ }^{19)}$.

\section{3）リンパ瘻}

患肢の外傷や, 皮膚直下のリンパ管が拡張し水 疱を形成した部位からリンパが外に漏れだすこと でリンパ瘦となる．傷への処置と圧迫で改善する が，悪化すると潰瘍を形成することがあり，それ から蜂窩織炎に繋がる場合もあるため，早めの対 応が必要である。

\section{4）リンパ管肉腫 (Stewart-Treves 症候群)}

進行したリンパ浮腫の患肢にまれに発症する血 管肉腫を, Stewart-Treves 症候群と呼ぶ。この呼 び方は特に乳がん術後のリンパ浮腫に合併した場 合のみに用いられていたが，最近はその他の部位 でもリンパ浮腫に続発して起こるリンパ管肉腫を このように呼ぶようになっている.

発症率はきわめて低いが悪性度は高い.リンパ 浮腫出現後，発症までの期間は $10 〜 20$ 年前後と いわれ，一般に，浮腫の進行を防ぐことで発症の
リスクを下げることができると考えられている ${ }^{20)}$.

\section{治療の基本：}

\section{複合的理学療法または複合的疎泄理学療法}

リンパ浮腫の保存的治療としては, 1892 年 Von Winiwarter がベッド上安静, 四肢挙上, 包 帯法, 運動を含む治療法を記述している. リンパ ドレナージ療法の起源は 1936 年にフランスで発 表された Emil Vodderによるもので，それを Foeldi らが医療分野で受け継ぎ欧州で開始し，米国へと 広がった. Foeldi は，その治療法を複合的理学療 法 (Complex decongestive physical therapy : CDP) または複合的疎泄理学療法 (Decongestive lymphatic therapy : DLT) と呼び，患肢へ貯留したリ ンパを排出するために集中的な治療を行う第一段 階と, 浮腫が改善した状態を維持する第二段階と に分けて説明し ${ }^{21)}$. 1998 年のアメリカがん学会 (American Cancer Society) 総会でDLT という用 語の使用に合意が得られている.

\section{1. スキンケア}

患肢では, リンパ流の不良により感染を起こす

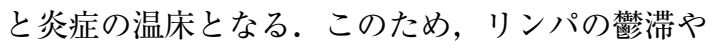
感染の危険がある行為は厳禁で, リンパの流れを 阻害したり，外傷や細菌に污染されるようなこと は避けるように注意する，注意点を表 4 にまと

表 4 日常生活での注意点

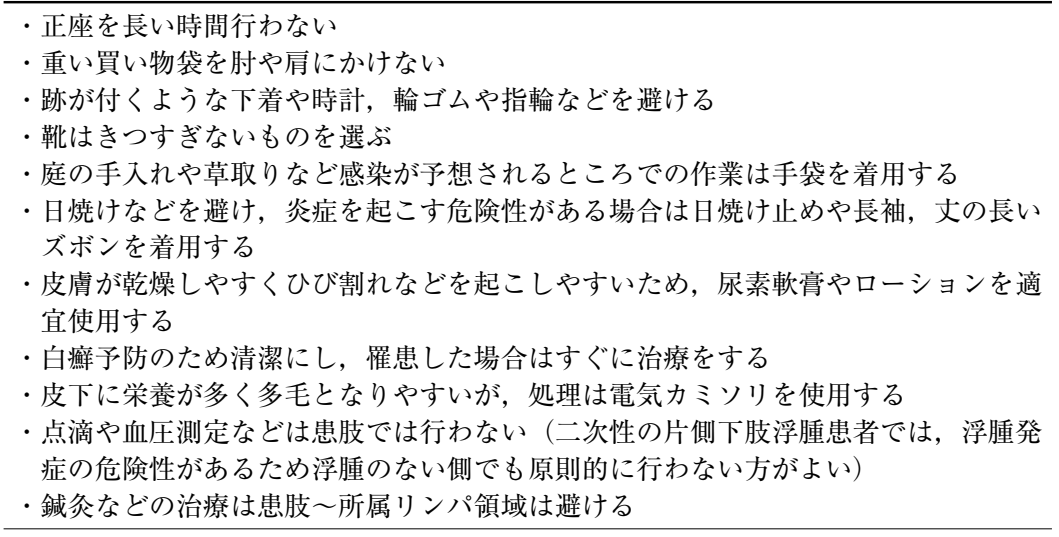

乳がん, 子宮がんの術後で浮腫がない場合でも, 生活上の注意を守ることで発症の 危険性を減らすことができると考えられる 
めた.

\section{2. 用手的リンパドレナージ（Manual Lymph Drainage : MLD)}

リンパドレナージは，基礎疾患や皮膚の状態， 合併症の有無などを確認し, 施行の可否を検討し てから行う，感染による炎症がある場合や，浮腫 の原因が心疾患や心不全，深部静脈血栓症である 場合は禁忌となる ${ }^{22)}$.

\section{1）MLD の基本的手技}

最も基本的なドレナージは患肢挙上である．患 肢を心臓より高い位置に保つが，高すぎると関節 部でリンパの流れを阻害するため $10 〜 15 \mathrm{~cm}$ 程 度の挙上でよい. 一力所に圧迫がかかるとそこで 流れが悪くなるため, 座布団や枕, 折りたたんだ 薄い布団など使用する.

挙上のみでは排出できないリンパ液を毛細リン パ管へ取り达みリンパ管内で移動させ, 最終的に 静脈へ戻し浮腫を軽減させるのが MLD である. 基本的な手技は，患肢に手のひらを密着させるよ うに当て，皮膚をずらすように柔らかく円を描き ながらリンパを誘導したい方向へ撫でる。蒰留フ イラメントにより毛細リンパ管の末端が引っ張ら
れリンパ液を取り达むことと，取り込んだリンパ 管内のリンパを移動させることが目的で，4つの 基本手技（皮膚に手掌をぴったりと当て，前述の ゆっくり円を描く，前方へ皮膚を動かす，上肢な どの細い部位でのくみ上げる，すくうように動か すなどの手技）がある ${ }^{23)}$. ただし，線維化など皮 膚の硬化がある場合にはそれをほぐす別の手技が 必要となってくる ${ }^{23)}$.

基本的なマッサージ方法を覚えると家庭でも自 分で行える（セルフマッサージ）が，治療開始時 や浮腫の悪化などがある場合は医師の診察などを 受けた上で，手技を熟知したセラピストからの指 導を受けることが望ましい。

\section{2）MLDの手順}

MLD では，流れが悪いリンパ管を避けバイパ ス機能により別のリンパ管を経由して静脈までの 道筋を作る. 静脈へと流入する最終地点に近い部 位から徐々に末梢へと MLDを行い, 流れを改善 させてから再度末梢から近位方向へとリンパ液を 進めてゆく ${ }^{23)}$. 例えば乳がん術後の右上肢浮腫に は，図 3 のように右腋窩を避けて右の鼠径部ま たは左腋窩へとリンパを誘導する。まず，リンパ が静脈に流入する両鎖骨上窩と頸部のマッサージ
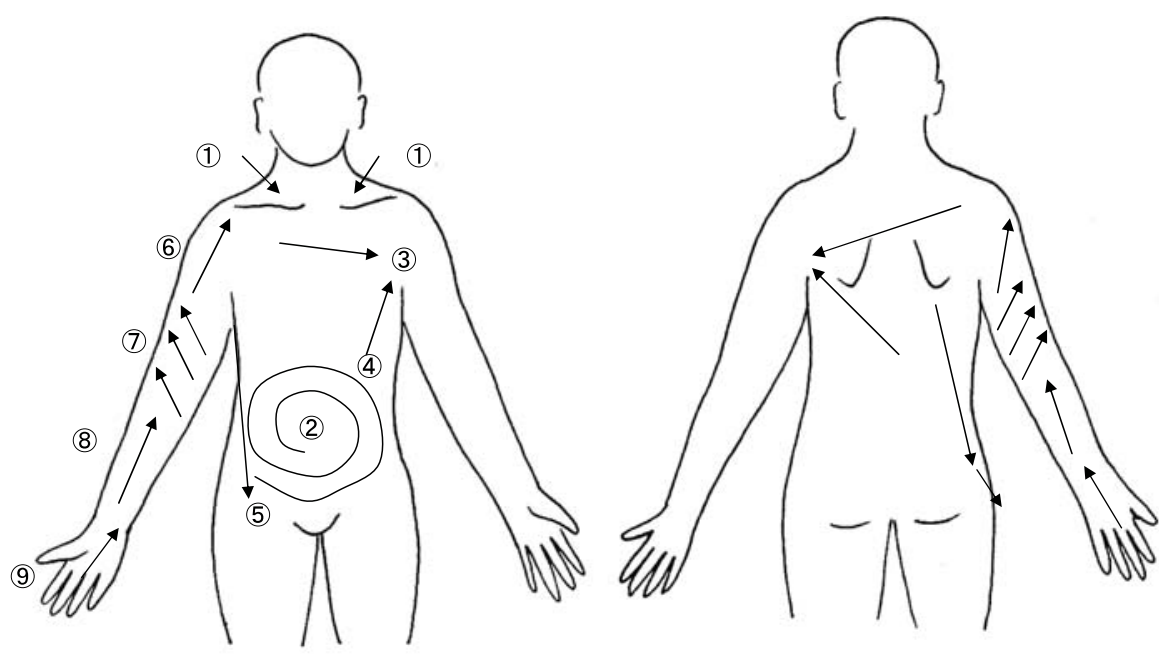

図 3 二次性右上肢リンパ浮腫のマッサージの手順

数字はマッサージの順番を示している. 矢印の方向に向かい, 矢印の先端部から矢尻の方向へ当 てた手をずらしながらマッサージを行ってゆく．体幹前面を施行後，後面も同様の手順で行う．

(1)から(9)まで行った後は，逆に(9)から施行する. 
を最初に行い，続いて腹部のマッサージや腹式呼 吸をし，深部へリンパを誘導する先である左腋窩 と右鼠径部のマッサージを行う. 次に患肢の上腕 から肩, 前腕から上腕, 手から上腕方向へマッサ ージを行いリンパの流れを作った後，最終的にこ れまでの流れと逆に末梢から中枢へとマッサージ をしてゆく．障害ごとのリンパ誘導先について表 5 にまとめた ${ }^{24)}$.

\section{3. 圧迫療法：弾性包帯によるバンデージ，圧 迫着衣の使用}

圧迫療法は，ドレナージ施行後に細くなった患 肢の維持と，圧迫をした上で運動をすることでさ らに筋収縮によるリンパドレナージ効果を期待す るという 2 つ意味がある. 方法としては， シ ヨートストレッチ弾性包带を使用するバンデージ 法と, 弾性スリーブやストッキングといった圧迫 着衣を使用する方法の 2 種類があり，各々の特

表 5 浮腫の部位と誘導先のリンパ節領域

\begin{tabular}{c|l}
\hline 浮腫の部位 & 誘導先のリンパ節 \\
\hline 右上肢 & 左腋窩, 右鼠径部 \\
\hline 左上肢 & 右腋窩, 左鼠径部 \\
\hline 右下肢 & 右腋窩 \\
\hline 左下肢 & 左腋窩 \\
\hline 両下肢 & $\begin{array}{l}\text { 右下肢は右腋窩 } \\
\text { 左下肢は左腋窩 }\end{array}$
\end{tabular}

二次性下肢浮腫では, 対側へ明らかな浮腫が無くても発 症する危険があるため, 同側の腋窩のみへ誘導する。一 次性の下肢浮腫では対側の鼠径部への誘導も行われる.
徵を表 6 にまとめた ${ }^{25)}$.

MLD 後に患肢が細くなってもそのまま外部か らの圧迫がなければ再度腫れを来すため，ドレナ ージ後は常に圧迫療法が必要となる ${ }^{22)}$.

\section{1）バンデージ法}

バンデージは, 主に治療の開始時に浮腫の軽減 を目的として行われる.軟膏などで皮膚の湿潤後, ストッキネットのような筒状包带を装着. その後 手指・足趾へ 1 本ずつ伸縮ガーゼ包帯を巻き, 手指と足趾を除いた部位をパッティング包帯（巻 き綿）で包んだ後，弾性包带を巻く．治療初期は， 皮膚の状態を確認しながら毎日バンデージを交換 し MLDを施行する。

2）圧迫着衣：弾性ストッキング・弾性スリーブ バンデージでは，手技に慣れることや浮腫の状 態を見ながらの調整が必要となるが，実際に 24 時間の管理を患者自身で行うことは難しいため, 日常生活では圧迫着衣を使用することが多い。

\section{a）使用着衣の選択}

上肢用としてスリーブ，下肢用としてストッキ ングがあり，浮腫の部位や患肢の状態に合わせ 種々の圧迫着衣を選択して使用する. 両下肢浮腫 や下腹部〜陰部にかけての浮腫がある場合や，片 側下肢でも左右差が大きくなければパンティスト ッキングタイプを, 両下肢のサイズが異なってい たり，腰部〜腹部と下肢とのバランスが合わない 場合は片脚ストッキングを使用する．片脚ストッ キングは製品によってガーターベルトがないとず り落ちて効果がなかったり, 大腿上部で食い达む

表 6 圧迫療法：バンデージ法と圧迫着衣の違い

\begin{tabular}{|c|c|c|}
\hline & バンデージ法 & 圧迫着衣 \\
\hline 対象患者 & $\begin{array}{l}\text { 浮腫の程度に関係なく，患肢の } \\
\text { 状態にあわせて行える. }\end{array}$ & $\begin{array}{l}\text { 既製品ではサイズが限られており, } \\
\text { 浮腫が強い場合などでは着用が難 } \\
\text { しいこともある. }\end{array}$ \\
\hline 施行時期 & $\begin{array}{l}\text { 浮腫の加療開始時期：浮腫の減 } \\
\text { 少を期待する時期 }\end{array}$ & $\begin{array}{l}\text { 主に浮腫の維持期に用いるが, 加 } \\
\text { 療開始時に使用することもある. }\end{array}$ \\
\hline 施行しやすさ & $\begin{array}{l}\text { 必要に応じ一日 } 1 \text { ～} 2 \text { 回巻き替 } \\
\text { えを要することもあり，手順に } \\
\text { 習熟する必要がある. }\end{array}$ & 着脱は容易である. \\
\hline $\begin{array}{l}\text { 日常生活上の } \\
\text { 制限の有無 }\end{array}$ & $\begin{array}{l}\text { 手指・足趾より包帯を巻くこと } \\
\text { で，作業や家事などに制限がで } \\
\text { る. }\end{array}$ & $\begin{array}{l}\text { 着用したまま仕事や家事なども可 } \\
\text { 能である. }\end{array}$ \\
\hline
\end{tabular}


ようになって同部で痛みを訴えることがある，既 製品の使用が困難な場合はオーダーメイドとなる が，值段は既製品よりも高額である. 図 4 に使 用頻度の高いストッキングの種類を示す.

スリーブやストッキングはメーカーや素材によ って耐久性が異なる。最長で 6 力月程度使用で きるものもあるが，一般的にはそれよりも早く緩 くなることが多い，着脱時に緩さを感じたり浮腫 が以前より増強するようであれば新しいものを購 入する方がよい.

\section{b）着圧の選択}

一般に, リンパ浮腫で使用される圧迫着衣は, 深部静脈血栓症予防のために使用されるものより も圧の強いものを用いる. 圧迫力は, クラス 1 : 20〜30 $\mathrm{mmHg}$ ，クラス $2: 30 \sim 40 \mathrm{mmHg}$ ，クラ ス $3 ： 40 \sim 50 \mathrm{mmHg}$ のように段階付けされてい るが，上肢ではクラス 1 または 2 , 下肢では 2 ま たは 3 のものが多く使用される.

着用にはコツと力を要し, 高齢の患者で圧が強 いものが使用困難な場合には弱圧のものを重ね履
きする方法もある．圧が弱めでも周径の減少は期 待でき, 重量感や脱力感などの症状もあわせて改 善されることが多い26). 周径が減少してゆく過程 で皮膚を圧迫して圧痕ができる場合にはまだ皮下 にリンパ液の貯留があり，着圧やサイズの調整に よりさらに浮腫が減少する可能性が高い.

\section{c) 使用前後の注意}

着用前に測定した周径を基準に最適なサイズの 圧迫着衣を使用してもらい，周径の減少にあわせ て小さいものへ変更してゆく，そのため，必ず圧 迫着衣はその形状や仕様, サイズ, 着圧が異なる ものを複数用意して患者ヘレンタルし，しびれ感， 上端や関節部などでの絞扼感などが無いことを確 認しながら周径変化がほぼ不変となったところで 個人用を購入してもらう。特に, 着用初期ではき つい着衣に抵抗があることも多く，使用しやすい ものを選び，効果を実感することを通じ圧迫着衣 の有用性や必要性を理解してもらうことが大切で ある。

通常，圧迫着衣は起床から就寝まで活動中は常

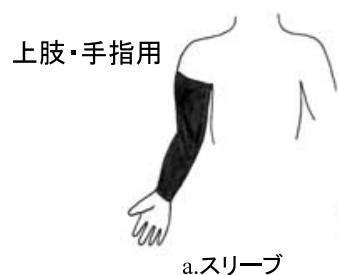

下肢用
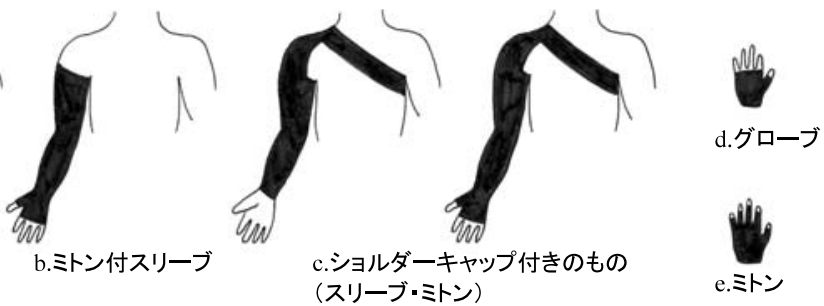

(スリーブ・ミトン)

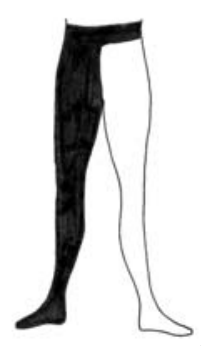

h.片脚ストッキング

（補助用のベルト付）

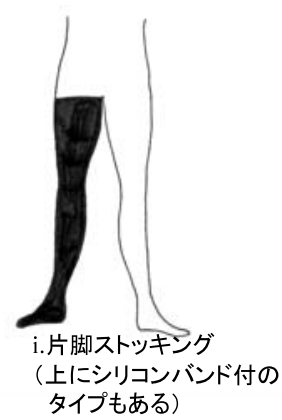

図 4 一般に使用される圧迫着衣

膝下のストッキングは, 途中で絞まる可能性があり一般にリンパ浮腫では使用しない。下肢用 でつま先はあるもの，ないものの 2 種類あり . 
時着用するが，夜間に浮腫が増強したり，着衣を 外すとだるさがあり睡眠に支障を来す場合は夜間 着用してもよい. 日中と同じ圧のものを着用する か, 圧の弱いものを使用するかは適宜装着感を確 認して選択する.

\section{4. 圧迫をした上での適度な運動}

MLD などのリンパ誘導手技と共に, 圧迫着衣 やバンデージを施行した上での運動は, 筋活動に より皮膚のマッサージ効果とリンパ流を増強させ て循環を促す効果がある。ただし, 圧迫なしの運 動は血流が増加することで末梢でのリンパ産生が 増加し浮腫が悪化する可能性もあり，かならず圧 迫が必要である.

運動のメニューは, 負荷の強い筋力増強訓練で は浮腫が悪化したり痛みが出現することもあり, 負荷が軽いリズミカルな繰り返し運動を行う. 水 泳や水中での歩行なども水圧によるマッサージ効 果が期待できるが, 患肢に創がある場合は避け る.

\section{5. その他の治療法}

1）空気式圧迫療法（Pneumatic compression therapy, PCT)

空気式マッサージ器は, 空気が入るカフに患肢 を入れカフに空気を送り込み加圧することでリン パの流れを促す．多く用いられるのは，カフがい くつかの空気室に分けられ，末梢から順に圧迫と 開放を繰り返す波動マッサージ器（メドマー®， ハドマー $\left.{ }^{\circledR}\right)$ である. 加圧時の空気圧は，一般に は皮膚に軽く圧がかかる程度の $30 \sim 40 \mathrm{mmHg}$ 前 後の弱圧で 30 分程度から始める ${ }^{27)}$. PCTではリ ンパ管内のリンパを中枢へ運ぶ作用が期待されて おり，流れが悪いリンパ管に強い力でリンパを押 し上げると，流れることができなかったリンパが 溜まり表在性リンパ管を損傷する可能性がある.

また, カフは患肢のみをカバーするため腋窩や体 幹, 鼠径部にリンパが貯留し同部の浮腫や線維化 を来す可能性があることから， PCT 後は MLDを 施行し, 患肢へのリンパ液の再貯留を防ぐため圧 迫療法が必要である。

\section{2）交感神経節ブロック}

野田らは，下肢リンパ浮腫に対し腰椎硬膜外ブ ロックおよび腰部交感神経節ブロックが効果的で あると報告している ${ }^{28)}$ 。その効果は, 浮腫による 交感神経の過剩刺激を減少させ下肢循環が改善さ れること, また, 動脈・静脈圧を減少させ, 毛細 血管の動脈側で起こる血管から間質への水の流出 が減少し, 静脈側での間質から血管内への流入が 高まるためと考えられる。

\section{3）内服治療}

薬物治療には, 利尿剤, ベンゾピロン類, メリ ロートエキスなどが使用されることが多い。ただ し，利尿剂は全身の水分を強制的に排出するのみ で, 電解質のバランスを崩す可能性もあり根本的 な解決とならない29). またベンゾピロンには肝障 害の報告があり ${ }^{30)}$ あまり用いられない。牛車腎 気丸 ${ }^{31,32)}$ などの漢方薬は, 圧迫療法などと併用し た上での改善が報告されているが，内服のみの効 果については未だ検討が必要である.

\section{4) 外科的治療}

これまで，浮腫となっている組織を切除する Charles 法や, Sistrunk 法, または, リンパ系を再 建しリンパ誘導をはかる Kondoleon 法, Thompson 法など種々の方法が施行されてきた ${ }^{33,34)}$. 現在は, リンパ管と細静脈とを吻合する顕微鏡下リンパ管 細静脈吻合術 ${ }^{35)}$ が行われるようになり，主にリ ンパ管の閉鎖や消失がない症例でその有効性が報 告されている.

\section{患者の負担や現在の問題点について}

\section{1. 医療費やその他の金銭的負担}

リハとして MLD と PCT な゙でリンパ浮腫の 治療を行うと理学療法・作業療法として医療費の 請求が可能である. 治癒は難しいため, 浮腫の改 善のため集中的な治療を行い, 症状が安定したと ころで生活の中にセルフケアを中心とした対応を 導入することが最善と考えられる，ただ，適切な 時期に適切な治療を受けられる体制づくりは必要 であり，リンパ浮腫に携わる医師に加え，がん治 療に当たる医師や看護師, 理学療法士 ・作業療法 
士などの理解なしには難しい.

また，弾性包帯，圧迫着衣の定期的な購入は大 きな経済的負担となっている．青森県内でも療養 費の給付申請を行い，コルセットなどの治療用装 具と同様に支給されるケースが出てきているが， 各地区担当者にその支給決定は一任されており申 請自体を全く受け付けないところもある。これま で申請がない，患者が少ないとして却下されてい るところもあり，今後は問題を抱えている患者の 実数を明らかにしてゆく必要があると思われる.

\section{2. 治療機関への速やかな連携の必要性}

患者は, リンパ浮腫の治療を受けるようになる までに，がん治療を行った医療機関やかかりつけ の病院などで浮腫について相談をしていることが 多いが, 浮腫の治療や日常生活の注意などへの言 及はあまりされていなかったり, 適切な医療機関 への紹介が遅れがちになってしまい, 当部でも発 症から紹介まで 5 ～10 年程度経過しているもの も多い. 専門クリニックは少なく, また都市部に 多いことから地方ではなかなか包括的な治療が受 けられない。ただ，全国には患者の会などのよう に，リンパ浮腫への理解を高めるため日常のケア やMLDの講習会を開催したり，近くの医療機関 の紹介なども行ってくれる組織もある. 医療者, 患者が共にリンパ浮腫への認識を高め, 適切な治 療方法やサポートが受けられる施設の情報を多く の場所で得られるような体制づくりも必要と考え られる。

\section{ま と め}

リンパ系の特徵, リンパ浮腫とその要因, 診断, 治療についてまとめた，現在，まだリンパ浮腫へ の対応が十分に行える施設は少なく, とくに MLD は限られた施設でしか行われていない。し かし，浮腫を出現初期から発見すれば，適切な日 常生活での対応や圧迫着衣の使用などで良好にコ ントロールされる症例も多い. そのため，なるべ く早期からの加療が開始できるようリハに関わる 医療者はもちろんのこと，がんなどの治療に当た
るスタッフも含めて，この疾患に関する知識が普 及する必要があると思われる。

\section{文献}

1）廣田彰男：リンパ浮腫とは. リンパ浮腫の理解とケア (廣田彰男, 丸口ミサ卫 編)。学研, 東京, 2004; pp 2-3

2）廣田彰男：基礎研究の進歩 浮腫の局所性因子 リン パ循環系とリンパ管運動調節. 日本臨床 2005 ; 63 : 3742

3）小川佳宏：リンパの基礎知識. リンパ浮腫 手足のむ くみを改善させる正しい知識を。保健同人社，東京， $2003 ;$ pp $4-11$

4）廣田彰男：リンパ循環の基礎知識. 浮腫の理解とケア (廣田彰男, 丸口ミサ卫 編)。学研, 東京, 2004; pp 4-12

5）小川佳宏：リンパ浮腫とは. リンパ浮腫 手足のむく みを改善させる正しい知識を。保健同人社, 東京, $2003 ;$ pp $12-23$

6）岩田広香：リンパ浮腫 適切なケアの知識と技術（季 羽倭文子, 志真泰夫，丸口ミサエ 監訳)，2003； pp $23-42$

7）小川佳宏：リンパ浮腫の疫学および診断.リンパ浮腫 診療の実際一現状と展望（加藤逸夫 監修 松尾 沉 編)，文光堂，東京， $2003 ; p p ~ 31-45$

8) Kocak $Z$, Overgaard J : Risk factors of arm lymphoedma in breast cancer patients. Acta Oncol $2000 ; 39$ : 389-392

9) Tiwari A, Cheng KS, Button M, Myint F, Hamilton G : Differential diagnosis, investigation and current treatment of lower limb lymphoedema. Arch Surg 2003 ; $138: 152-161$

10）上山武史, 阿部芳伸：四説：静脈疾患とリンパ浮腫の 治療 (9). Medical Postgraduates $2003 ; 41: 25-34$

11) Harris SR, Hugi MR, Olivotto IA, Levine $M$ : Clinical practice guidelines for the care and treatment of breast cancer : 11. Lymphedema. CMAJ 2001 ; 164 : 191-199

12) Rockson SG, Miller LT, Senie R, Brennan MJ, CasleySmith JR, Födi E, Födi M, Gamble GL, Kasseroller RG, Leduc A, Lerner R, Mortimer PS, Norman SA, Plotkin CL, Rinehart-Ayres ME, Walder AL : American Cancer Society Lymphedema Workshop Workgroup III Diagnosis and Management of Lymphedema. Cancer 1998 ; 83 (Suppl) : 2882-2885

13）松本茂男：16 浮腫・血行障害 臨床リハビリテーシ ョン別冊 脳卒中リハビリテーション外来診療（浅山 滉, 石神重信, 住田幹男, 里宇明元 編). 医歯薬出版, 東京, $1997 ;$ pp 146-149

14）山崎善弥, 馬場紀明, 斉藤浩一, 戸川達男, 天羽輝 彦：浮腫の診かたと治療リンパ浮腫の診断と治療. 診断と治療 $2002 ; 90: 754-759$

15) Cornish BH, Chapman M, Thomas BJ, Ward LC, Bunce IH, Hirst C : Early diagnosis of lymphedema in postsurgery breast cancer patient. Annals N Y Acad Sci $2000 ; \mathbf{9 0 4}$ : 571-575 
16) International Society of Lymphology : Consensus document of the International Society of Lymphology. The diagnosis and treatment of peripheral lymphedema. Lymphology $2003 ; \mathbf{3 6}: 84-91$

17）小川佳宏：リンパ浮腫の病態. リンパ浮腫 診療の実 際么現状と展望 (加藤逸夫 監修, 松尾 沉 編), 文光 堂, 東京, $2003 ;$ pp 21-29

18）小林範子, 藤野敬史, 櫻木範明：リンパ浮腫に合併す る蜂窩織炎の予防と管理. 臨床看護 $2004 ; 30$ : 13431347

19）小川佳宏：リンパ浮腫の合併症. リンパ浮腫 手足の むくみを改善させる正しい知識を. 保健同人社, 東京, $2003 ;$ pp 24-29

20）兼古理恵，杉山貞夫，新保孝一，高橋博之，斎藤和哉， 後藤田裕子, 村岡俊二, 佐藤利宏 : 子宮癌根治術後に 発症したStewart-Treves 症候群. 皮膚臨床 $2000 ; 42$ : 415-418

21）飯野京子：リンパ浮腫 適切なケアの知識と技術（季 羽倭文子, 志真泰夫, 丸口ミサエ 監訳), 中央法規, 2003 ; pp 93-108

22）佐藤佳代子：保存的リンパ浮腫治療—“複合的理学療 法’について一. 日本臨床 $2005 ; 63: 144-153$

23）佐藤佳代子：リンパ浮腫保存的治療; 複合的理学療法 について．臨床看護 $2004 ; 30: 1348-1358$

24）小川佳宏：リンパ浮腫の治療. リンパ浮腫 手足のむ くみを改善させる正しい知識を。保健同人社, 東京, $2003 ;$ pp 38-61

25）伊藤鮎美：圧迫療法. リンパ浮腫の理解とケア（廣田 彰男, 丸口ミサ卫 編集). 学研, 東京, 2004 ; pp 75-
86

26）細川賀乃子，近藤和泉，岩田 学：当院における続発 性下肢リンパ浮腫へのアプローチ. リハビリテーショ ン医学 $2005 ; \mathbf{4 2 : 8 0}$

27）丸口ミサエ：リンパ浮腫 適切なケアの知識と技術 (季羽倭文子, 志真泰夫, 丸口ミサエ 監訳), 中央法 規, $2003 ;$ p 215-222

28）野田雅也，伊東英樹，工藤隆一，水沼正弘，山川 康， 佐野敬夫：骨盤内リンパ節摘出後下肢リンパ浮腫に対 する硬膜外ブロック法および腰部交感神経節ブロック 法の効果. 日本産婦人科学会雑誌 $1998 ; \mathbf{5 0}: 947-953$

29）廣田彰男：薬物療法. リンパ浮腫の理解とケア（廣田 彰男, 丸口ミサ卫 編)。学研, 東京, $2004 ; \mathrm{p} 96$

30）齋藤健人, 宮田哲郎, 重松 宏: 外科医の立場からみ たリンパ浮腫の現況. 臨床看護 $2004 ; 30: 1373-1376$

31）阿部吉伸：リンパ浮腫に対する牛車腎気丸の効果. 漢 方医学 $2002 ; 25: 284-287$

32) 内 尚子, 伊奈奈帆美, 日高隆雄, 齋藤 滋: 子宮頚 癌治療後の下肢リンパ浮腫に対して牛車腎気丸および 大防風湯が有効であった 1 例. 産婦人科漢方研究のあ ゆみ No. 21, 診断と治療社, 東京, 2004 ; pp 79-84

33）廣田彰男：手術療法. リンパ浮腫の理解とケア（廣田 彰男, 丸口ミサ卫 編)。学研, 東京, $2004 ;$ p 97

34）光嶋 勲, 森口隆彦, 梶原康正：リンパ浮腫の治療. 手術 1996 ; 50 : 1715-1723

35）光嶋 勲, 稲川喜一, 衛藤企一郎, 森口隆彦: 形成外 科・最近のトピックス 8 . リンパ浮腫に対するリン パ管細静脈吻合術. 日本外科学雑誌 $1999 ; 100$ : 551556 